\title{
Microhabitats Affect Population Size and Plant Vigor of Three Critically Endangered Endemic Plants in Southern Sinai Mountains, Egypt
}

\author{
Amal M. Fakhry ${ }^{1, *(1)}$, Ali El-Keblawy ${ }^{2}\left(\mathbb{D}\right.$, Hatem A. Shabana ${ }^{3,4}$, Ibrahim El Gamal ${ }^{4}(\mathbb{C}$ \\ and Amir Shalouf ${ }^{4}$ \\ 1 Botany and Microbiology Department, Faculty of Science, Alexandria University, Alexandria 21568, Egypt \\ 2 Department of Applied Biology, Faculty of Science, University of Sharjah, \\ P. O.Box 27272 Sharjah, United Arab Emirates; akeblawy@sharjah.ac.ae \\ 3 Sharjah Seed Bank and Herbarium, Sharjah Research Academy, \\ P.O. Box 27272 Sharjah, United Arab Emirates; hatem_shabana@yahoo.com \\ 4 Nature Conservation Sector, Egyptian Environmental Affairs Agency, Cairo 11728, Egypt; \\ Ibrahim_abdelrafee@yahoo.com (I.E.G.); Amirshalouf@yahoo.com (A.S.) \\ * Correspondence: amalfakhry@live.com
}

Received: 9 April 2019; Accepted: 29 May 2019; Published: 31 May 2019

\begin{abstract}
Endemic species on mountains often have narrow altitudinal ranges and are more threatened at the higher altitudes, especially with climate changes. However, plants could use special microhabitats at the mountain tops as proper places for surviving the climate change (i.e., refugia). We assessed population attributes of three critically endangered endemic species (Primula boveana Decne ex Duby, Rosa arabica Crep., and Silene leucophylla Boiss.) in two growing seasons (2006/2007 and 2013/2014), differing in the received rainfalls in microhabitats at the high mountains of southern Sinai. Both P. boveana and S. leucophylla had very small population size, but significantly increased in the 2013/2014 growing season which received above average rainfalls. The population of $R$. arabica is the smallest (around 40 individuals) and did not increase, even after the increase in rainfalls. Whereas P. boveana is present in fewer sites and grew in small number of specific microhabitats, both S. leucophylla and R. arabica were recorded in most studied sites and habitat types. Unlike R. arabica, both P. boveana and S. leucophylla were recorded in caves and steep slopes and on the top of the mountains. This indicates that these sheltered mist microhabitats are the best for future conservation of these species after climate change.
\end{abstract}

Keywords: endangered species; climate change; population size; conservation

\section{Introduction}

Mountains harbor a unique and large portion of the world's biodiversity. Many species at high elevations are isolated, and consequently, have limited number of climatic niches as compared to lowland vegetation communities. Consequently, greater portion of endemic species are present in the plant communities of mountains than the lowland communities [1,2]. In addition, mountains are more susceptible to the impacts of rapid climate changes [3]. As endemic species often have narrow altitudinal ranges of distribution, they are more threatened at the higher altitudes [4]. The high-altitude ecosystems are largely controlled by climatic constraints, and many plants reside close to their climatic limits of survival [2-5].

The geography of the Sinai Peninsula has a special importance and uniqueness. Sinai is the meeting point of Asia and Africa, and therefore, its flora has evolved in isolation. Floristically, it is one of the richest of all phytogeographical regions of Egypt [6]. Sinai supports about 1285 species, of which 
about 800 species are recorded in southern part [6]. Moustafa and Klopatek [7] stated that more than 61 rare species were recorded in southern Sinai, with some of them being endangered or threatened endemics and near endemics. Khedr et al [8] analyzed a database for the flora the Egyptian flora book of Tackholm [9] and stated that 34 of the southern Sinai plants (4.3\% of Egypt flora) are endemics. Primula boveana Decne ex Duby, Rosa arabica Crep., and Silene leucophylla Boiss. are three endemic species recorded as very rare and critically endangered endemics in their narrow range of distribution at the high mountains of South Sinai, Egypt [6]. After the last glacier retreatment, these species, as most of the other endemic species in the region, remained and grew in either mesic or cooler habitats, such as the top of the mountains [6]. As a result, these species became critically endangered. For example, according to the IUCN Red List of threatened species, R. arabica, which is nano-phanerophyte shrub, has been listed as one of the world's 100 most threatened species [10]. Similarly, P. boveana, which is a perennial hemicryptophyte, has been reported as one of the rarest plant species worldwide [11,12]. Furthermore, the population size of S. leucophylla, another perennial hemicryptophyte in Saint Katherine protectorate, is about 50 individuals distributed over seven locations [13-15]. The high environmental pressures expected from future global warming place these endemic species in fragile ecological habitats. Global warming would increase the rate of evapotranspiration, and this might put these species under more environmental pressures that would lead to their extinction. It has been reported that Egypt, including the Saint Katherine Mountains, showed overall mean annual temperature increases of $0.62^{\circ} \mathrm{C}$ per decade during the period 1971-2000 [16], which is greater than the average global increase of $0.17^{\circ} \mathrm{C}$ per decade [17].

Temperature decreases with the increase in altitude. Therefore, an upslope movement for mountainous species is expected after climate change [18,19]. Several studies have reported movements of mountain biota upward as a result of global climate warming [2,20-22]. For example, Harsch et al [23] analyzed a global dataset of 166 mountainous sites around the world for which tree line dynamics had been recorded since 1900 and reported upward advances of tree lines. In addition, Kelly and Goulden [18] reported that the average elevation of the dominant plant species rose by $\approx$ $65 \mathrm{~m}$ during 30 years in a $2314 \mathrm{~m}$ elevation gradient in southern California's Santa Rosa Mountains. They attributed this shift to changes in regional climate. In South Sinai, Coals et al. [24] indicated a significant overall upslope shifts in mean upper altitudinal limits in the high-mountain flora. In addition, climatic change is expected to be associated with drought. The high rate of evapotranspiration is expected to be higher with the increase in global warming, even at the high altitudes of the mountains. Therefore, these factors would threaten critically endangered species at the top of the mountains. The presence of the critically endangered endemic species of the mesic habitats at the top of the Saint Katherine Mountains of southern Sinai might accelerate their extinction. This is particularly possible with climate change scenario, which will be associated with an increase in the temperatures and a reduction in rainfalls (i.e., increase the repeated drought). The aim of the present study, therefore, was to assess the changes in population sizes, individual sizes, and vitality of the three endemic P. boveana, $R$. arabica, and S. leucophylla during a seven-year period in different habitats with varying amounts of received rainfall. In addition, the study aimed at determining the environmental factors associated with the distribution of individuals of the three species in the different habitat types (e.g., caves, gorges, wadi beds, and terraces) and topographic microclimates (e.g., slope, aspect, and altitude) of the mountains. This would help determine the important environmental factors limiting the distribution of these endemic species. This would also determine the most suitable habitats that could be used as refugia for their conservation after climate change.

\section{Study Area}

The study area is located at the Saint Katherine Mountains, which is situated in the southern part of Sinai and is a part of the upper Sinai massif. It is located between $28^{\circ} 30^{\prime}$ to $28^{\circ} 35^{\prime}$ North and $33^{\circ} 55^{\prime}$ to $34^{\circ} 30^{\prime}$ East. The arid to hyper-arid climate of the Saint Katherine Mountains is characterized by an ecological uniqueness due to its diversity in landforms, geologic structures, and climate [25]. 
The high elevation and diversity of mesic habitats in the ecosystem of the Saint Katherine Mountains support the incidence of a big proportion of endemic and rare plants. The soil has granitic origin, as it is formed mainly from mountains weathering. The regular run-off creates shallow soils with bedrock close to the surface [26]. The characters of land surfaces, altitudinal gradient, and landform types offer microhabitats dominated by vegetation that is very specialized to grow in the mountain habitats. This vegetation is sparse and characterized by a variety of chasmophytic and xerophytic plant species [7].

The annual precipitation (rain and snow) in the Saint Katherine Mountains over 25 years (1970 - 1994) is $45 \mathrm{~mm}$ per year. The higher elevations receive more precipitation (100 mm per year) [27]. This indicates the hyper-aridity of the Saint Katherine Mountains region. Precipitation occurs as a snow on the mountaintops and usually lasts two to four weeks. Based on the meteorological data of the Saint Katharine Protectorate weather station, the highest amount of rainfall received in the Saint Katherine Mountains during the period of the study was in growing season October 2013-May 2014 (145.6 mm, Table 1). However, the growing season October 2006-May 2007 received only $22.2 \mathrm{~mm}$, which is below the long-term average $(45 \mathrm{~mm})$. In years that receive above average rainfall, floods resulting from convective rains have been observed during the winter and spring. In addition, the mean air temperature ranged from $5.4^{\circ} \mathrm{C}$ to $25.1^{\circ} \mathrm{C}$. The lowest temperature is in January and February, and the highest in July and August [28]. In a recent nine-year record (2006-2014) in the Saint Katharine Protectorate weather station, the mean air temperature ranged from $5.2{ }^{\circ} \mathrm{C}$ to $25.2^{\circ} \mathrm{C}$, with the lowest temperature in January and the highest in August (Table 1).

Table 1. Monthly variation in average temperatures $\left({ }^{\circ} \mathrm{C}\right)$ and rainfall $(\mathrm{mm})$ in the Saint Katherine area from 2006 to 2014, except for 2011 (Saint Katharine Protectorate Weather Station). Temp: Average temperature, RF: Sum rainfall.

\begin{tabular}{|c|c|c|c|c|c|c|c|c|c|c|c|c|c|c|c|c|}
\hline \multirow{2}{*}{ Mon } & \multicolumn{2}{|c|}{2006} & \multicolumn{2}{|c|}{2007} & \multicolumn{2}{|c|}{2008} & \multicolumn{2}{|c|}{2009} & \multicolumn{2}{|c|}{2010} & \multicolumn{2}{|c|}{2012} & \multicolumn{2}{|c|}{2013} & \multicolumn{2}{|c|}{2014} \\
\hline & Temp & RF & Temp & RF & Temp & RF & Temp & RF & Temp & RF & Temp & RF & Temp & RF & Temp & RF \\
\hline Jan. & 7.5 & 0.0 & 6.8 & 2.6 & 5.7 & 2.2 & 7.9 & 0.0 & 11.5 & 0.5 & 5.2 & 9.0 & 10.0 & 50.5 & 10.0 & 2.0 \\
\hline Mar. & 12.4 & 1.2 & 11.7 & 1.0 & 16.2 & 0.0 & 12.1 & 0.2 & 15.4 & 0.0 & 10.7 & 0.8 & 14.1 & 0.0 & 13.0 & 2.4 \\
\hline Apr. & 16.2 & 1.0 & 16.4 & 5.8 & 19.8 & 0.0 & 16.7 & 0.0 & 18.3 & 0.0 & 18.3 & 0.0 & 15.6 & 0.0 & 18.4 & 6.9 \\
\hline May & 20.4 & 0.4 & 22.8 & 0.0 & 19.6 & 0.0 & 19.8 & 0.0 & 21.6 & 10.5 & 21.7 & 0.4 & 21.4 & 0.0 & 20.8 & 11.7 \\
\hline Aug. & 25.4 & 0.0 & 24.5 & 0.0 & 25.2 & 0.0 & 24.0 & 0.0 & 27.6 & 0.1 & 24.9 & 0.0 & 24.6 & 0.0 & 25.3 & 0.0 \\
\hline Sep. & 22.7 & 0.0 & 21.6 & 0.0 & 24.1 & 0.8 & 20.6 & 0.0 & 24.6 & 0.0 & 23.9 & 0.9 & 22.5 & 0.0 & 22.0 & 0.0 \\
\hline Oct. & 18.8 & 0.0 & 20.1 & 0.0 & 17.5 & 0.0 & 18.4 & 0.0 & 22.9 & 0.0 & 19.5 & 0.0 & 17.3 & 0.0 & 17.9 & 0.0 \\
\hline Nov. & 11.3 & 0.0 & 13.9 & 0.0 & 13.1 & 0.0 & 14.9 & 0.0 & 17.0 & 0.0 & 13.1 & 23.9 & 14.0 & 0.0 & 12.9 & 0.0 \\
\hline Dec. & 7.4 & 4.8 & 10.4 & 0.0 & 12.9 & 0.0 & 8.2 & 0.2 & 11.4 & 0.3 & 9.2 & 3.3 & 6.6 & 8.2 & 11.2 & 18.6 \\
\hline Total & 16.6 & 13.4 & 17.1 & 17.4 & 17.7 & 3.0 & 16.8 & 0.4 & 19.5 & 11.8 & 17.3 & 38.3 & 17.1 & 145.6 & 19.0 & 41.6 \\
\hline
\end{tabular}

\section{Materials and Methods}

In 2007, 38 sampling plots (stands) distributed in 16 sites were surveyed. These plots were selected to cover the distribution of the three endemic species (P. boveana, R. arabica, and S. leucophylla) in the different habitat types of the populations in the Saint Katherine Protectorate in South Sinai. The plots represented five major types of habitats (wadi beds, gorges, slopes, terraces, and caves). A Global Positioning System was used to record the positions of the plots. The survey was conducted between the end of March and June 2007. The plot size was $5 \mathrm{~m} \times 5 \mathrm{~m}$. For each plot, the following topographic environmental factors were recorded: (a) Elevation (ranged between 1645 and $2014 \mathrm{~m}$ above sea level (asl); (b) slope angle, which was estimated using clinometer; (c) aspect, which is the direction that a slope faces. It identifies the steepest downslope direction from each cell to its neighbors. Here, aspect was measured using digital elevation model (DEM) from ArcGIS 10.2. The aspect map of a certain site that is resulted from the Arc map program displays the aspect of each raster cell grouped into compass directions that the surface faces at that site. It is measured clockwise in degrees from 0 (due north) to 360 (again due north), coming full circle. Flat areas having no downslope direction are 
given a value of -1 . We categorized slope aspect into seven directions (west, northeast, northwest, southeast, southwest, and flat); and (d) extent of occurrence, which is the area located within the shortest continuous imaginary boundary that can be drawn to encompass all the known, inferred, or projected sites of occurrence, excluding cases of vagrancy. Arc View GIS 10.2 was used to plot the study sites and estimate the extent of occurrence.

The growth and reproductive parameters of the three studied endemic plants (e.g., canopy height and diameters, and numbers leaf, inflorescences, and fruits) were recorded. In addition, size index was calculated as average of plants heights and diameters. Plant density was estimated as number of rooted plants per $100 \mathrm{~m}^{2}$. Plant vitality was measured as a ratio between number of leaves and plant size. Size of the photosynthetic organs (leaves) was suggested to be a good indicator for plant vitality [29]. Typically, vigorous plants have more leaves for doing photosynthesis, compared to weaker plants.

Frequency of occurrence was calculated as the number of stands in which a species occurred over the total number of survived plots. Density was calculated as the number of plants of a certain species per $100 \mathrm{~m}^{2}$. Despite using $25 \mathrm{~m}^{2}(5 \mathrm{~m} \times 5 \mathrm{~m})$ stands, density was calculated per $100 \mathrm{~m}^{2}$ to give reasonably bigger values. Relative change $(\mathrm{RC})$ in a certain variable was calculated as a percentage of the difference between 2007 and 2014 to the value of that variable in 2007.

In 2014, we increased the number of plots based on the increase in area of occurrence of the three species. Therefore, 58 sampling plots distributed in 18 sites were surveyed, including the 38 plots that were surveyed in 2007. The selected plots covered the distribution of the three species by 2014. Surveys were carried out between the end of March and June 2014 as described above. All measurements and calculations were conducted as described above.

One-way ANOVA was used to assess each of the main factors (year, altitude, habitat, slope, and aspect) on the following variables: Population size (number of individuals), plant size (size index), and vitality (leaf number/size) of the three endemic species. Number of individuals was square root transformed, but both size index and vitality were log-transformed. These transformations improved the normality of the distribution of the data. Tukey's test (Honestly significant differences, HSD) was used to estimate the least significant differences between the means at $P=0.05$. All statistical methods were performed using SYSTAT, version 13.0.

\section{Results}

\subsection{Primula boveana}

The population size of $P$. boveana is very small. It is significantly affected by year, altitude, and slope of the mountains (Table 2). The total population size increased from 176 plants recorded at five locations in 2007 to 1065 plants at six locations in 2014, which is more than a five-fold increase. The total areas occupied by this species in the different locations were 225 and $250 \mathrm{~m}^{2}$ in 2007 and 2014, respectively. The density per $100 \mathrm{~m}^{2}$ significantly increased from 78 in 2007 to 426 in 2014 plants. Interestingly, most of the plants of 2014 were newly recruited seedlings (Table 3).

The population of P. boveana was distributed into five and six subpopulations (locations) in 2007 and 2014, respectively. The subpopulation sizes were significantly increased during the seven years in four locations $(P<0.001)$, but insignificantly decreased in only one (Sad Abo Hebake, $P>0.05)$. The highest increases were in Wadi Graginya (multiplied by 8.61) and Maen Shinara (multiplied by 6.14, Table 4). 
Table 2. Results of one-way ANOVA (F-values) showing the effects of year, altitude, habitat, slope, and aspect on population size, plant size, and vitality of three endemic species in the Saint Katherine Protectorate Mountains.

\begin{tabular}{|c|c|c|c|c|c|c|}
\hline Species & Variable & Year & Altitude & Habitat & Slope & Aspect \\
\hline Primula & No of individuals & $28.150^{* * *}$ & $20.080^{* * *}$ & 2.350 & $9.920 * *$ & 2.680 \\
\hline \multirow[t]{2}{*}{ boveana } & Size index & $7.940 * *$ & 0.288 & 1.438 & 0.156 & 0.435 \\
\hline & Plant vitality & 0.700 & 2.549 & 0.546 & 0.365 & 0.296 \\
\hline \multirow{3}{*}{$\begin{array}{c}\text { Rosa } \\
\text { arabica }\end{array}$} & No of individuals & 0.018 & $7.329 * *$ & $3.104 *$ & 0.093 & $2.400 *$ \\
\hline & Size index & 3.506 & 2.646 & 0.328 & $4.024 *$ & 0.469 \\
\hline & Plant vitality & 1.172 & $11.111^{* * *}$ & 2.071 & $7.328 * *$ & $2.765 *$ \\
\hline \multirow{3}{*}{$\begin{array}{c}\text { Silene } \\
\text { leucophylla }\end{array}$} & No of individuals & 0.794 & 0.807 & 0.871 & $5.824 * *$ & $3.168^{* *}$ \\
\hline & Size index & 0.767 & $4.793^{* *}$ & $6.341^{* *}$ & 2.590 & $2.544 *$ \\
\hline & Plant vitality & $15.591^{* * *}$ & $10.586^{* * *}$ & $9.096^{* * *}$ & $4.033 *$ & $5.802 * * *$ \\
\hline
\end{tabular}

Table 3. Relative change over seven years (2007-2014) in number of individuals and population attributes in three endemic species growing in the Saint Katherine Protectorate Mountains.

\begin{tabular}{|c|c|c|c|c|}
\hline Species & Variable & 2007 & 2014 & RC \\
\hline \multirow[t]{9}{*}{ Primula boveana } & No of subpopulations & 5 & 6 & 20.0 \\
\hline & No of habitats & 3 & 3 & 0.0 \\
\hline & Number of recoded plots & 9 & 10 & 11.1 \\
\hline & Frequency of occurrence & 23.7 & 17.2 & -27.2 \\
\hline & Total No of individuals & 176 & 1065 & $505.1 * * *$ \\
\hline & Density (plants/100 m²) & 78.2 & 426 & $444.7^{* * *}$ \\
\hline & Total areas occupied $\left(\mathrm{m}^{2}\right)$ & 225 & 250 & 11.1 \\
\hline & Size index $(\mathrm{cm})$ & 18.0 & 14.9 & $-17.2^{* * *}$ \\
\hline & Vitality & 2.53 & 2.53 & 0.0 \\
\hline \multirow[t]{9}{*}{ Rosa arabica } & No of subpopulations & 10 & 11 & 10.0 \\
\hline & No of habitats & 4 & 4 & 0.0 \\
\hline & Number of recoded plots & 19 & 20 & 5.3 \\
\hline & Frequency of occurrence & 50.0 & 34.5 & -31.0 \\
\hline & Total No of individuals & 40 & 42 & 5.0 \\
\hline & Density (plants/100 m²) & 8.4 & 8.2 & -2.4 \\
\hline & Total areas occupied $\left(\mathrm{m}^{2}\right)$ & 475 & 500 & 5.2 \\
\hline & Size index $(\mathrm{cm})$ & 321.5 & 466.8 & 45.2 \\
\hline & Vitality & 36.3 & 29.7 & -18.2 \\
\hline \multirow[t]{9}{*}{ Silene leucophylla } & No of subpopulations & 8 & 10 & 25.0 \\
\hline & No of habitats & 3 & 3 & 0.0 \\
\hline & Number of recoded plots & 10 & 28 & $180^{* *}$ \\
\hline & Frequency of occurrence & 26.3 & 48.3 & 83.4 \\
\hline & Total No of individuals & 33 & 109 & $230.3^{* * *}$ \\
\hline & Density (plants/100 m²) & 13.2 & 15.6 & 18.2 \\
\hline & Total areas occupied & 250 & 700 & $180^{* * *}$ \\
\hline & Size index $(\mathrm{cm})$ & 6.5 & 20.8 & 220.0 \\
\hline & Vitality & 3.5 & 25.8 & $634.2 * * *$ \\
\hline
\end{tabular}

${ }^{*} p \leq 0.05,{ }^{* *} p \leq 0.01$, and ${ }^{* * *} p \leq 0.001$, according to one-way ANOVA testing the difference between 2007 and 2014. 
Table 4. Relative change over seven years (2007-2014) in number of plants, sizes, and plant vitality in three endemic species growing in different regions of the Saint Katherine Protectorate Mountains.

\begin{tabular}{|c|c|c|c|c|c|c|c|c|c|}
\hline \multirow{2}{*}{ Region } & \multicolumn{3}{|c|}{ Primula boveana } & \multicolumn{3}{|c|}{ Rosa arabica } & \multicolumn{3}{|c|}{ Silene leucophylla } \\
\hline & $\begin{array}{l}\text { No of } \\
\text { plants }\end{array}$ & Size & Vitality & $\begin{array}{l}\text { No of } \\
\text { plants }\end{array}$ & Size & Vitality & $\begin{array}{l}\text { No of } \\
\text { plants }\end{array}$ & Size & Vitality \\
\hline Abo Giefa & & & & & & & 50 & 39.5 & $91.3 *$ \\
\hline Abo Twaita & & & & 57.1 & 0.4 & $-53.4 *$ & & & \\
\hline Abo-Hamman & & & & & & & -100.0 ** & -100.0 & -100.0 \\
\hline El-Maeen & & & & 0 & 4.2 & 2.4 & 400 & 48.0 & -27.2 \\
\hline Farsh El Romana & & & & -50 & $-31.7 * * *$ & $-98.1^{* * *}$ & & & \\
\hline Farsh El Sefsafa & & & & & & & $100.0^{* * *}$ & 100.0 & 100.0 \\
\hline Farsh Elia & & & & & & & $\overline{100.0^{* * *}}$ & 100.0 & $\overline{100.0}$ \\
\hline Farsh mesela & & & & & & & $-100.0^{*}$ & -100.0 & $\overline{-100.0}$ \\
\hline Gebel El-Ahmar & $100.0^{* * *}$ & 100.0 & 100.0 & -40 & $112.0 * * *$ & $-30.3 * *$ & $100.0 * * *$ & 100.0 & 100.0 \\
\hline Kahf El Gholah & $\overline{86.1 * * *}$ & $-62.1 * * *$ & $\overline{83.6}$ & -14.3 & $-33.8^{* * *}$ & 182.7 & & & \\
\hline Maen Shinara & $614.3 * * *$ & $-69.3^{* * *}$ & 236.8 & & & & 300 & -12.7 * & $-5.6^{* * *}$ \\
\hline Mousa Mountain & & & & & & & $100.0^{*}$ & 100.0 & 100.0 \\
\hline Musa Gorge & $364.3 * * *$ & 115.7 & -50.1 & 0 & 4.3 & 22.7 & $100.0^{* *}$ & 100.0 & $\overline{100.0}$ \\
\hline Sad Abo Hebake & -33.3 & $-76.3 *$ & 69.7 & 10 & $68.0^{* * *}$ & -70.5 & & & \\
\hline Shag Tinia & & & & -50 & $469.9^{* * *}$ & $-92.7^{*}$ & -100.0 & -100.0 & -100.0 \\
\hline Shaq Saqr & & & & 0 & 18.5 & -14.7 & -28.6 & 12.5 & -2.1 \\
\hline Sheqeaf Mislla & & & & 100.0 & 100.0 & 100.0 & & & \\
\hline Wadi Elshak & & & & & & & 50 & 18.0 & 7.4 \\
\hline Wadi Graginya & $861.5^{* * *}$ & $63.4^{* *}$ & -7.7 & & & & $500.0^{* * *}$ & $84.8^{*}$ & $563.6^{* * *}$ \\
\hline Wadi Tinia & & & & 50 & $117.1^{* * *}$ & -38.4 & & & \\
\hline
\end{tabular}

The presence of $P$. boveana was restricted to three habitat types at the different locations. The number of plants was significantly increased during the seven years in both gorges (multiplied by 3.12) and slopes (multiplied by 6.35, Table 5). The presence of $P$. boveana depended on slope aspect, as plants were recorded only in east- and northeast-facing aspects. The number significantly increased during the seven years of the study in the two aspects. This species was not recorded in the gentle slope $\left(<55^{\circ}\right)$. The occurrence of $P$. boveana was significantly greater at the steeper slopes $\left(>85^{\circ}\right)$, as compared with the gentle slopes $\left(55-85^{\circ}\right)$. The increase between 2007 and 2014 was much greater in steeper slope $(7.1$ fold) than in the gentle slope (1.34 fold). In addition, P. boveana preferred the highest altitudes. The total number plants increased from 91 in 2007 to 650 in 2014 at $>2000 \mathrm{~m}$ asl, but from 45 to 73 at $<1800 \mathrm{~m}$ asl (Table 5).

The size index of $P$. boveana plants was significantly affected by the year, but not by the other ecological factors (Table 2). It decreased by $17.2 \%$ during the seven years (Table 3 ). This might be attributed to the big number of newly recruited plants in 2014 that had smaller sizes. The plant sizes significantly decreased in three sites, but significantly increased in Wadi Graginya and was not affected in Musa Gorge. Plant vitality, as a measure of number of leaves per plant size, did not significantly change during the seven years $(P>0.05)$, (Tables 2 and 5$)$.

\subsection{Rosa arabica}

Rosa arabica has a very small, but stable population size. A total of 40 and 42 individuals were recorded in 2007 and 2014, respectively. The population size was significantly affected by habitat, altitude, and aspect of the mountains $(P<0.05$, Table 2$)$. However, this small number of individuals were evenly distributed in a larger number of locations (10 and 11 locations in 2007 and 2014, respectively, Tables 3 and 4) and habitat types (four in both 2007 and 2014, Tables 2 and 5). In addition, the total areas covered the distribution range of $R$. arabica were 475 and $500 \mathrm{~m}^{2}$ in 2007 and 2014, respectively. The density per $100 \mathrm{~m}^{2}$ was 8.4 in 2007 and 8.2 in 2014 (Table 3). 
Table 5. Relative change over seven years (2007-2014) in number of plants, sizes, and plant vitality in three endemic species growing in different habitats and topographic features of the Saint Katherine Protectorate Mountains.

\begin{tabular}{|c|c|c|c|c|c|c|c|c|c|c|}
\hline \multicolumn{2}{|c|}{ Microhabitat type } & \multicolumn{3}{|c|}{ Primula boveana } & \multicolumn{3}{|c|}{ Rosa arabica } & \multicolumn{3}{|c|}{ Silene leucophylla } \\
\hline & & $\begin{array}{l}\text { No of } \\
\text { plants }\end{array}$ & Size & Vitality & $\begin{array}{l}\text { No of } \\
\text { plants }\end{array}$ & Size & Vitality & $\begin{array}{l}\text { No of } \\
\text { plants }\end{array}$ & Size & Vitality \\
\hline \multirow{5}{*}{ Habitat } & Caves & 50 & -12.8 & -46.1 & - & - & - & - & - & - \\
\hline & Gorges & $312.5^{* * *}$ & -12.4 & 9.8 & 5.6 & $57.6^{* * *}$ & -16.4 & -37.5 & 40.3 & 0.7 \\
\hline & Slopes & $634.9^{* * *}$ & -34.7 & 71.9 & 0 & $-35.4^{* *}$ & 202.5 & $910.0^{* * *}$ & $20.3^{* * *}$ & $174.2^{* * *}$ \\
\hline & Terraces & - & - & - & 0 & 12 & $-77.0^{* *}$ & $-100.0^{*}$ & -100.0 & -100.0 \\
\hline & Wadi Bed & - & - & - & 13.3 & $47.5^{* * *}$ & $-43.0^{* * *}$ & - & - & - \\
\hline \multirow{7}{*}{ Aspect } & E & $161.1^{* * *}$ & -34.6 & -6.3 & -11.1 & -5.6 & -62 & 50 & 18 & 8.3 \\
\hline & $\begin{array}{c}\text { Flat (no } \\
\text { aspect) }\end{array}$ & & & & 20 & $-21.6^{* * *}$ & $-50.8^{* * *}$ & - & - & - \\
\hline & NE & $607.9^{* * *}$ & -11 & 1.7 & 21.4 & $31.6^{* * *}$ & -15.5 & $266.7^{* * *}$ & $123.1^{* * *}$ & $571.7^{* * *}$ \\
\hline & NW & - & - & - & 100.0 & 100.0 & & $333.3^{* * *}$ & $219.8^{* * *}$ & -33.2 \\
\hline & $\mathrm{SE}$ & - & - & - & & & & -100.0 & -100.0 & -100.0 \\
\hline & SW & - & - & - & -33.3 & $149.8^{* * *}$ & $-80.9^{* * *}$ & 100.0 & 100.0 & 100.0 \\
\hline & $\mathrm{W}$ & - & - & - & -20 & $248.7^{* * *}$ & -4.3 & 100.0 & 100.0 & 100.0 \\
\hline \multirow{3}{*}{ Slope } & $<55^{\circ}$ & - & - & - & 17.9 & $49.8^{* * *}$ & $-23.8^{* * *}$ & 20 & $271.8^{* *}$ & 88.4 * \\
\hline & $55-85^{\circ}$ & $133.9^{* * *}$ & $-58.2 * * *$ & -14.5 & -15.4 & $30.2 * * *$ & $-43.5^{*}$ & $800.0^{* * *}$ & $368.2 * * *$ & $930.3^{* * *}$ \\
\hline & $>85^{\circ}$ & $709.4^{* * *}$ & 13.3 & 11.2 & - & - & - & $83.3^{*}$ & 27.4 & $373.0 * * *$ \\
\hline \multirow{3}{*}{$\begin{array}{l}\text { Altitude } \\
\text { (m asl) }\end{array}$} & $<1800$ & $62.2 * *$ & $-79.7^{* * *}$ & -2.2 & -9.1 & $52.1^{* * *}$ & $-62.4^{* * *}$ & -37.5 & -22.8 & -49.0 \\
\hline & $1800-2000$ & $805.0^{* * *}$ & $186.0^{* * *}$ & -8.4 & 33.3 & $47.3^{* * *}$ & $-20.8^{* *}$ & $330.8^{* * *}$ & $230 * *$ & $602.9^{* * *}$ \\
\hline & $>2000$ & $614.3^{* * *}$ & $-69.3^{* * *}$ & 39.1 & - & - & - & $2150.0^{* * *}$ & $1906.3^{* * *}$ & $1333.1^{* * *}$ \\
\hline
\end{tabular}

100 and -100 means that a variable was not present in 2007 and 2014 , respectively. ${ }^{*} p \leq 0.05,{ }^{* *} p \leq 0.01$ and

$* * * p \leq 0.001$, according to one-way ANOVA testing the difference between 2007 and 2014

The size index of $R$. arabica plants was not affected significantly by any factor $(P>0.05)$ except slope of mountains $(P<0.05$, Table 2$)$. The plant sizes were significantly greater in 2014 than in 2007 in four locations $(P<0.001)$, but significantly decreased in other two $(P<0.001)$ and were not affected in five locations $(P>0.05$, Table 4$)$. In addition, size index significantly increased $(P<0.001)$ in two habitats (gorges and wadi bed), but significantly decreased $(P>0.01)$ in the slopes. During the seven years, plant sizes of $R$. arabica were significantly increased in three aspects (northeast, west, and southwest, $P<0.05)$, but significantly decreased $(P<0.001)$ in the flatlands (Table 5).

$R$. arabica was recorded in all aspects of the mountains except the southeast. The species was recorded only in the gentle $\left(<55^{\circ}\right)$ and gentle $\left(55-85^{\circ}\right)$, but not in the steepest slope $\left(>85^{\circ}\right)$. During the seven years, the population size increased at the gentle slope $\left(<55^{\circ}\right)$ but decreased at the gentle $\left(55-85^{\circ}\right)$ slopes. In addition, R. arabica was recorded in up to $2000 \mathrm{~m}$ asl, but the gentle altitudes were the best for its occurrence (Table 5).

The vitality of $R$. arabica plants was significantly affected by all topographical factors (slope, aspect, and altitude, $P<0.05$, Table 2). The average vitality insignificantly decreased by $18.2 \%$ between 2007 and 2014 (Table 3). Vitality significantly decreased during the seven years in four locations (Abo Twaita, Farsh El Romana, Gebel El-Ahmar, and Shag Tinia, Table 4) and in two habitats (terraces and wadi beds). In addition, the significant decreases in plant vitality were recorded in two aspects (flat summit and southwest), in gentle slopes $\left(<55^{\circ}\right)$, and in low altitudes $(<1800$, Table 5$)$.

\subsection{Silene leucophylla}

Silene leucophylla had a small population size that grew significantly during the seven years of the study. The total population increased from 33 plants in 2007 to 109 plants in 2014 (the increases were more than 2.3-fold). The population size was not affected by year, altitude, or habitat $(P>0.05)$, but was significantly affected by slope and aspect of the mountains $(P<0.01$, Table 2$)$. In addition, the total number of plots in which S. leucophylla was recorded increased significantly during the seven years, increasing from 10 in 2007 to 28 plots in 2014 . However, the increase in plant density during the 
same period was not significant. The total areas occupied by S. leucophylla in its distribution range almost tripled during the seven years, from $250 \mathrm{~m}^{2}$ in 2007 to $700 \mathrm{~m}^{2}$ in 2007 (Table 3).

Subpopulations of S. leucophylla were found in eight locations in 2007 and increased to 10 locations in 2014. However, three subpopulations of 2007 disappeared in 2014 (Abo-Hamman, Farsh mesela, and Shag Tinia). Instead, other five subpopulations appeared in 2014 (Farsh El Sefsafa, Farsh Elia, Gebel El-Ahmar, Mousa Mountain, and Musa Gorge). Their sizes significantly increased in 2014 in the subpopulation Wadi Graginya (Table 4)

The number of plants of S. leucophylla increased significantly $(P>0.001)$ between 2007 and 2014 in one habitat types (slopes; multiplied by 9.1 increase), in two aspects (northeast and northwest; multiplied by 2.67 and 3.33 increases, respectively). Low numbers of S. leucophylla were recorded in gentle slopes and at lower altitudes. Most of the plants were present in steep slopes $\left(>55^{\circ}\right)$ and higher altitudes $(>1800 \mathrm{~m})$. The increase during the seven years was higher at $55-85^{\circ}$ (eight-fold), compared with the steepest slopes $\left(>85^{\circ}, 0.8\right.$-fold). In addition, the increase was much greater at the highest altitudes (>2000 $\mathrm{m}$ asl, 21-fold) than that at moderate altitude (1800-2000 $\mathrm{m}$ asl, 3.3-fold). S. leucophylla was recorded in all aspects except flatlands. However, it disappeared from some aspects and appeared in others in 2014 (Table 5).

Size and vitality of $S$. leucophylla were significantly affected by most of the factors $(P<0.05$, Table 2$)$. Vitality increased during the seven years by 6.34 -fold (Table 3). During the study period, both size and vitality significantly increased in one subpopulation (Wadi Graginya), but significantly decreased in another subpopulation (Maen Shinara, $P<0.05$ ). Vitality also increased in Abo Giefa (Table 4). Similarly, both size index and vitality significantly increased $(P<0.001)$ in one habitat types (slopes). In relation to aspects, size increased during the seven years in two aspects (northeast and northeast), but vitality increased in one (northeast, Table 5).

Plant vitality was increased during the study periods in all slope categories, but size index increased in slopes up to $85^{\circ}$, but not at the steepest slopes $\left(>85^{\circ}\right)$. In addition, both plant size and vigor significantly increased in altitudes above $1800 \mathrm{~m}$ asl (Table 5).

\section{Discussion}

There are six habitats in Saint Katherine Protectorate, each has its own specific environmental conditions, landscapes, and flora. These habitats are caves, gorges, slopes, terraces, basins, and wadi beds [30]. Several studies have reported habitat specificity for endemic species of Southern Sinai [6,31-34]. These microhabitats are shaped by altitude, aspect, and degree of slope, which in turn shape the spatial distribution and patterns of vegetation $[35,36]$. Our results showed that the three studied endemic taxa are growing in different types of specific microhabitats. The three species were recorded in the gorges and slopes. In addition, two species were recorded in terraces (R. arabica and S. leucophylla), and one species in the caves (P. boveana) and wadi beds (R. arabica).

The IUCN has categorized P. boveana as globally critically endangered. It has been reported as one of the rarest plant species worldwide [11,12]. It was also reported that the population of P. boveana was abundant in the year 1832 at the Saint Katherine Mountains [11]. However, the population was reduced to around 2000 individuals in 1991 [37], and 336 in 2007 [12]. In the present study, we recorded only 176 individuals in 2007, but this number increased significantly to 1065 individuals in 2014. Our results showed that the distribution of this species is limited to few locations and grows in small number of specific microhabitats, particularly the sheltered mountain areas, such as cliffs and caves of the steep slopes in the northeast mountain direction. Similarly, Moustafa and Kamel [38] recorded P. boveana among the plants that grow in caves and shaded gorges, mainly on rocky outcrops of high-moisture content (wet and shaded rocks) with very low temperatures $\left(3-10^{\circ} \mathrm{C}\right)$ at elevations of $2200-2400 \mathrm{~m}$. Zaghloul [39] recorded P. boveana only in few water springs in north-facing cliffs at high elevations in Saint Katherine. This author found that $P$. boveana was restricted to the caves and sheltered wet crevices of slopes, which is shaded most of the year. The distribution of P. boveana in cooler and mist microhabitats indicates that it is very sensitive to climate changes that would increase the temperatures. 
However, as the cliffs and caves receive less solar radiation, they would be less vulnerable to warming associated with climatic changes. These sites could be perfect future conservation refugia.

The high increase in population size and plant density of $P$. boveana in 2014 could be attributed to the higher amount of rainfall received in 2013/2014. Most of the individuals of $P$. boveana recorded in 2014 were newly recruited seedlings. According to Moustafa [25], the 2013/2014 growing season showed the highest recorded annual precipitation in the whole history of Sinai ( $>200 \mathrm{~mm}$ ). However, the smaller population size of $P$. boveana in 2007 (176 individuals) could be attributes to the lower amount of rainfalls received during 2006/2007 season ( $<20 \mathrm{~mm}$; [25]).

The small population size of $P$. boveana could be attributed to natural and/or anthropogenic effects. For example, several human activities have been considered among the factors that threaten the presence of $P$. boveana in the natural habitats $[40,41]$. These include, for example, overcutting, overgrazing, and reduction in water available to the plants [42]. In addition, the habitats of this species are facing several natural threats. Floods and cyclic drought are among these natural threats. The shallow soils of the very steep slopes maintain little water and consequently dry years might significantly increase plant mortality. In addition, plants in shallow soils could be uprooted with the floods in years receive more rainfalls. The Saint Katherine Mountains region receives destructive floods every seven to 10 years $[40,41]$.

The Sinai endemic wild rose, R. arabica, was qualified by the IUCN Red List of threatened species as critically endangered. It has been listed as one of the world's 100 most threatened species [10]. In the present study, $R$. arabica had very small population size (40 and 42 individuals in 2007 and 2014, respectively). Interestingly, the small number of $R$. arabica is distributed in more diverse sites and habitats as compared to P. boveana and S. leucophylla. It grows in most studied sites and habitats, except the very specific habitats, which are caves and high altitudes. According to [25], R. arabica grows in mountainous wadis and gorges with rocky grounds (40\%) and northwest-facing, steep granite slopes of up to $90^{\circ}$ on west. They were not recorded in the caves. The absence of $R$. arabica in the caves could be attributed to its large sizes, as it is a big shrub with a height up to $3 \mathrm{~m}$. In addition, the light intensity and quality inside the caves might not be suitable for the photosynthesis process. The absence of $R$. arabica from the caves would deprive them from advantages of the sheltered moist sites that might protect them from the higher temperatures and droughts of climate change. However, the absence of $R$. arabica from the top of the mountains might give them the chance to shift upslope after climate change. Our results also showed a significant decrease in vitality of mature individuals between 2007 and 2014. In addition, among the important threats that would reduce the plant numbers of $R$. arabica are overgrazing and over collection for the exploitation of the medicinal active constituents that are present in different organs of the plant [25]. The evaluation of the status of the protected populations of $R$. arabica showed that there is no real conservation plan for that species and it needs more protection, restoration, and reintroduction [25].

S. leucophylla is an endangered endemic perennial that grows in the rocky habitats of the St. Katherine Protectorate in southern Sinai, Egypt. We recorded a very small population size of S. leucophylla. The total number of individuals increased from 33 in 2007 to 109 in 2014. The significant increase was recorded in northeast and northwest steep slope habitats $\left(>55^{\circ}\right)$ and higher altitudes $(>1800 \mathrm{~m})$. The results of the present study also highlighted the disappearance of three subpopulations from 2007 to 2014 (Abo-Hamman, Farsh Mesela, and Shag Tinia), but other five subpopulations appeared in Farsh El Sefsafa, Farsh Elia, Gebel El-Ahmar, Mousa Mountain, and Musa Gorge in 2014. This indicates that the population of S. leucophylla is very dynamic. It can appear and disappear according to environmental conditions. This indicates that individuals of this species are sensitive to environmental stresses but could be also recruited easily upon the availability of the favorable conditions. Individuals of the new five populations appeared with the extraordinary high rainfall received in 2013/2014.

As mountains usually have conical shapes, upslope movement certainly results in range loss and may even lead to extinction of the plants at the top of the mountains [43]. It has been reported that 
range-restricted species and mountaintop species show severe range contractions [22-44]. Mountaintop species respond to global warming by shifting their range boundaries toward higher altitudes. For example, Lenoir et al. [20] showed that climate warming has resulted in a significant upward shift in species optimum elevation, averaging $29 \mathrm{~m}$ per decade in their comparisons of the altitudinal distribution of 171 forest plant species during 100 year in West Europe. In addition, Parmesan [21] provided evidence that woody plants at their upper altitudinal range boundaries have responded to global warming by dispersing to higher elevations. Consequently, global warming would negatively affect endemic plants growing in mesic microhabitats at high elevations of the Saint Katherine Mountains of southern Sinai. In Egypt and the Middle East, in general, the overall mean annual temperature has increased with $0.62{ }^{\circ} \mathrm{C}$ per decade during the period 1971-2000 [25]. This increase is greater than the overall average global trend, which is $0.17^{\circ} \mathrm{C}$ per decade [17]. In addition, the average warmest daily maximum temperatures of the Middle East has been increased by more than $1^{\circ} \mathrm{C}$ since the 1970s [16-45]. In our study, the increase in the overall mean annual temperature affected the local distribution of the studied species, especially P. boveana and S. leucophylla, which could have been moved upslope. Both are growing better and have higher vitality at the higher altitudes. In high mountains of southern Sinai, Coals et al. [24] also showed a significant overall upslope shift of plants in mean upper altitudinal limits. Many of the perennial herbs, trees, and small and big shrubs expanded their altitudinal ranges and showed long-term shifts in altitudinal range in the hyper-arid desert mountains of South Sinai [25]. The upslope movement of studied species, especially R. arabica, could be attributed to biotic stresses, especially overgrazing and overcutting that are higher at low and mid-elevations as compared to top mountains. The accessibility of the plants of these species could be less at the top mountains (Hatem Shabana, personal observation).

\section{Conclusions}

Both P. boveana and S. leucophylla grow at the top of the mountains. Therefore, their extinction under the global warming scenario is higher as compared to plant of the lower elevations. However, the tendencies of these species to grow in specific habitats that provide them shelter is a real advantage after global warming. The presence of species of the present study in specific microhabitats of the caves and sheltered wet cervices of slopes, which are shaded most of the year, indicates that these sites are the best for their conservation after climatic changes. The smaller areas of sheltered habitats make them more feasible for conservation. Consequently, conservation of mesic habitats should receive more priority. However, the few individuals of the critically endangered R. arabica are distributed in wider varieties of habitats, not including the moist and sheltered ones. As this species is exposed to overgrazing and overcutting, their conservation in enclosures would be a more practical option.

Author Contributions: Conceptualization, A.F. and A.E.K.; Data curation, H.S.; Formal analysis, A.F. and H.S.; Methodology, H.S., I.E. and A.S.; Supervision, A.E.K.; Writing - original draft, A.F.; Writing - review \& editing, A.F. and A.E.K.

Funding: This research received no external funding.

Acknowledgments: The authors thank the Saint Katherine Protectorate (Egyptian Environmental Affairs Agency) staff members specially Mohamed Kotb and Mohamed Hemid for the official support for this study. Thanks to Selim Mahana, who helped in the most field trips.

Conflicts of Interest: The authors declare no conflict of interest.

\section{References}

1. Beniston, M. Climatic Change in Mountain Regions: A Review of Possible Impacts. Clim. Chang. 2003, 59, 5-31. [CrossRef]

2. El-Keblawy, A. Impact of climate change on biodiversity loss and extinction of endemic plants of arid land mountains. J. Biodivers. Endanger. Species. 2014, 2, 120. [CrossRef]

3. Nogués-Bravo, D.; Araújo, M.B.; Martínez-Rica, J.P.; Errea, M.P. Exposure of global mountain systems to climate change. Glob. Environ. Chang. 2007, 17, 420-428. [CrossRef] 
4. Grabherr, G.; Gottfried, M.; Pauli, H. Climate effects on mountain plants. Nature 1994, 369, 448. [CrossRef]

5. El-Keblawy, A.; Khedr, A. Population structure and ecological role of Moringa Peregrina (Forssk.) Fiori. in the northwestern range edge at Hajar mountains. Plant Biosyst. 2015, 149, 1-10. [CrossRef]

6. Ayyad, M.A.; Fakhry, A.M.; Moustafa, A.A. Plant biodiversity in saint Catherine area of the Sinai peninsula, Egypt. Biodivers. Conserv. 2000, 9, 265-281. [CrossRef]

7. Moustafa, A.A.; Klopatek, J.M. Vegetation and landforms of the saint Catherine area, southern Sinai, Egypt. J. Arid Environ. 1995, 30, 385-395. [CrossRef]

8. Khedr, A.H.; Cadotte, M.W.; El-Keblawy, A.; Lovett-Doust, J. Phylogenetic diversity and ecological features in the Egyptian flora. Biodivers. Conserv. 2002, 11, 1809-1824. [CrossRef]

9. Täckholm, V. Students' Flora of Egypt, 2nd ed.; Cairo University: Cairo, Egypt, 1974.

10. Baillie, J.E.; Butcher, E.R. Priceless or Worthless? The World's Most Threatened Species; Zoological Society of London: London, UK, 2012; p. 63.

11. Richards, A.J. Primula; Timber Press: Portland, OR, USA, 2003.

12. Jimenez, A.; Mansour, H.; Keller, B.; Conti, E. Low genetic diversity and high levels of inbreeding in the Sinai primrose (Primula boveana), a species on the brink of extinction. Plant Syst. Evolut. 2014, 300, 1199-1208. [CrossRef]

13. El-Demerdash, M. The ex Situ Conservation Technical Report on Propagation of Medicinal Plants; MPCP, The Egyptian Environmental Affairs Agency (EEAA): Cairo, Egypt, 2007; p. 71.

14. El-Mawey, M. Technical Report on Restoration of Endangered Plant Species in st. Catherine Protectorate; MPCP, Egyptian Environmental Affairs Agency (EEAA): Cairo, Egypt, 2008; p. 31.

15. Saker, M.; El-Demerdash, M.; Allam, M.A. In vitro propagation and genetic characterization as effective tools for conservation of Silene leucophylla, grown in st. Katherine protected area, Sinai, Egypt. J. Genet. Eng. Biotech. 2011, 9, 21-27. [CrossRef]

16. Domroes, M.; El-Tantawi, A. Recent temporal and spatial temperature changes in Egypt. Int. J. Clim. 2005, 25, 51-63. [CrossRef]

17. IPCC. The Intergovernmental Panel on Climate Change; 3rd assessment report; IPCC: Geneva, Switzerland, 2001.

18. Kelly, A.E.; Goulden, M.L. Rapid shifts in plant distribution with recent climate change. Proc. Natl. Acad. Sci. 2008, 105, 11823-11826. [CrossRef] [PubMed]

19. Gottfried, M.; Pauli, H.; Futschik, A.; Akhalkasti, M.; Barancok, P.; Alonso, J.L.; Grabherr, G. Continent-wide response of mountain vegetation to climate change. Nature Clim. Chang. 2012, 2, 111-115. [CrossRef]

20. Lenoir, J.; Gégout, J.C.; Marquet, P.A.; De Ruffray, P.; Brisse, H. A significant upward shift in plant species optimum elevation during the 20th century. Science 2008, 320, 1768-1771. [CrossRef]

21. Parmesan, C. Ecological and evolutionary responses to recent climate change. Annu. Rev. Ecol. Evol. Syst. 2006, 37, 637-669. [CrossRef]

22. Root, T.L.; Price, J.T.; Hall, K.R.; Schneider, S.H.; Rosenzweig, C.; Pounds, J.A. Finger prints of global warming on wild animals and plants. Nature 2003, 421, 57-60. [CrossRef] [PubMed]

23. Harsch, M.A.; Hulme, P.E.; McGlone, M.S.; Duncan, R.P. Are treelines advancing? A global meta-analysis of treeline response to climate warming. Ecol. Lett. 2009, 12, 1040-1049. [CrossRef]

24. Coals, P.; Shmida, A.; Vasl, A.; Duguny, N.; Gilbert, F. Elevation patterns of plant diversity and recent altitudinal range shifts in Sinai's high-mountain flora. J. Veg. Sci. 2018, 29, 255-264. [CrossRef]

25. Moustafa, A.A.; Zaghloul, M.S.; Mansour, S.R.; Alsharkawy, D.H.; Alotaibi, M. Long term monitoring of Rosa arabica populations as a threatened species in south Sinai, Egypt. J. Biodivers. Endanger. Species. 2017, $5,197$.

26. Khafagia, O.; Hatabb, E.E.; Omar, K. Ecological niche modeling as a tool for conservation planning: Suitable habitat for Hypericum sinaicum in south Sinai, Egypt. Univers. J. Environ. Res. Tech. 2012, 2, 515-524.

27. Danin, A. Flora and vegetation of Sinai. Proc. R. Soc. Edinburgh. 1986, 89 B, 159-168. [CrossRef]

28. Moustafa, A.; Zaghloul, M.S. Environment and vegetation in the montane saint Catherine area, South Sinai, Egypt. J. Arid Environ. 1996, 34, 331-349. [CrossRef]

29. Kozlov, M.V.; Zvereva, E.L.; Zverev, V.E. Impacts of Point Polluters on Terrestrial Biota; Springer: Dordrecht, The Netherland, 2009; Chapter Soil quality; pp. 107-131.

30. Khedr, A. Assessment, classification, and analysis of microhabitats supporting globally significant plant species. In Conservation and Sustainable Use of Medicinal Plants in Arid and Semi-arid Eco-systems Project; Saint Katherine Protectorate, Egypt. EEAA, GEF \& UNDP: Cairo, Egypt, 2007. 
31. Shaltout, K.H.; Ahmed, D.A.; Shabana, H.A. Population structure and dynamics of the endemic species Phlomis aurea Decne in different habitats in southern Sinai peninsula, Egypt. Glob. Ecol. Conserv. 2015, 4, 505-515. [CrossRef]

32. Shaltout, K.H.; Ahmed, D.A.; Shabana, H.A. Distribution of the associated species with Phlomis aurea Decne along an elevation gradient in southeren Sinai, Egypt. Ecol. Mediterr. 2016, 42, 1.

33. Danin, A. Desert Rocks. A habitat which supports many species that were new to science in the last 40 years. Turk. J. Bot. 2008, 32, 459-464.

34. Abd EL-Wahab, R.; Zayed, A.; Moustafa, A.; Klopatek, J.; Helmy, M. Landforms, vegetation, and soil quality in south Sinai, Egypt. Catrina 2006, 1, 127-138.

35. Allen, R.B.; Peet, R.K. Gradient analysis of forests of the Sangre de Cristo Range, Colorado. Can. J. Bot. 1990, 68, 193-201. [CrossRef]

36. Busing, R.T.; White, P.S.; MacKende, M.D. Gradient analysis of old spruce-fir forest of the great Smokey Mountains circa 1935. Can. J. Bot. 1992, 71, 951-958. [CrossRef]

37. Al Wadi, H. Primula boveana and Jebel Katarina. Bull. Alp. Gard. Soc. 1993, 61, 68-70.

38. Moustafa, M.M.; Kamel, W.M. Ecological notes on the floristic composition and endemic species of saint Catherine mountains, south Sinai, Egypt. Qatar Univ. Sci. J. 1995, 15, 339-352.

39. Zaghloul, M.S. Ecological studies on some endemic plant species in south Sinai, Egypt. Master's Thesis, Suez Canal University, Ismailia, Egypt, 1997.

40. Zaghloul, M.S. Population ecology of genus Ballota growing in southern Sinai, Egypt. Ph.D. Thesis, Suez Canal University, Ismailia, Egypt, 2003.

41. Abd El-Wahab, R.H.; Zaghloul, M.S.; Moustafa, A.A. Conservation of medicinal plants in St. Catherine protectorate, south Sinai, Egypt. I. Evaluation of ecological status and human impact. In Proceedings of the International Conference on Strategy of Egyptian Herbaria, Giza, Egypt, 9-11 March 2004; pp. 231-251.

42. Omar, K.A. Evaluating the effectiveness of in-situ conservation on some endemic plant species in south Sinai, Egypt. Am. J. Life Sci. 2014, 2, 164-175. [CrossRef]

43. Colwell, R.K.; Brehm, G.; Cardelús, C.L.; Gilman, A.C.; Longino, J.T. Global warming, elevational range shifts, and lowland biotic attrition in the wet tropics. Science 2008, 322, 258-261. [CrossRef] [PubMed]

44. El-Keblawy, A.A.; Khedr, A.H.; Khafaga, T.A. Mountainous landscape vegetation and species composition at Wadi Helo: A protected area in Hajar mountains, UAE. Arid Land Res. Manag. 2016, 30, 389-399. [CrossRef]

45. Zhang, X.; Aguilar, E.; Sensoy, S.; Melkonyan, H.; Tagiyeva, U.; Ahmed, N.; Albert, P. Trends in Middle East climate extreme indices from 1950 to 2003. J. Geophys. Res. Atmos. 2005, 110, 1-12. [CrossRef] 